\title{
Apakah yang Memengaruhi Fenomena Migrasi Masuk ke Wilayah Perkotaan? Jurnal Ecces
}

\author{
Moh. Isa Ashari ${ }^{1}$, \\ Ahmad Kafrawi Mahmud ${ }^{2}$ \\ 1,2Program Studi IImu Ekonomi \\ Fakultas Ekonomi dan Bisnis Islam Universitas Islam Negeri Alauddin Makassar \\ Jl. Yasin Limpo, No. 36 Samata, Gowa Sulawesi Selatan \\ E-mail : kafrawi_a@ymail.com ${ }^{1}$
}

\section{Abstrak: Apakah yang Memengaruhi Fenomena Migrasi Masuk ke Wilayah Perkotaan?}

Dinamika kependudukan terjadi karena adanya dinamika kelahiran, kematian dan perpindahan penduduk terhadap perubahan-perubahan dalam jumlah, komposisi dan pertumbuhan penduduk. Pertumbuhan angkatan kerja yang tidak sebanding dengan penyediaan lapangan kerja yang berarti bahwa tingkat pengangguran semakin besar, keadaan tenaga kerja yang mendorong meningkatnya mobilisasi dikalangan penduduk. Perpindahan penduduk dari desa ke kota sebagian besar dipengaruhi oleh faktor ekonomi yaitu harapan untuk mendapatkan kesempatan kerja yang lebih baik dikota. Dengan tingkat upah yang lebih tinggi. Selain itu, semakin tingginya tingkat pendidikan akan mendorong penduduk untuk melakukan migrasi dengan tujuan untuk mendapatkan kesempatan kerja yang sesuai dengan tingkat pendidikannya. Tujuan dari penelitian ini adalah untuk mengetahui hubungan antara faktor-faktor yang mempengaruhi minat migrasi ke kota Makassar. Penelitian dilaksanakan di Kota Makassar dengan metode kuantitatif dan menggunakan data sekunder. Analisis model persamaan yang dilakukan dengan menggunakan pendekatan data panel. Hasil penelitian menunjukan terdapat empat faktor yang memengaruhi penduduk untuk bermigrasi ke Kota Makassar yaitu UMP, investasi, pengeluaran pemerintah dan kesempatan kerja. Dimana tingkat upah dan kesempatan kerja yang paling kuat pengaruhnya terhadap penduduk yang masuk ke Kota Makassar (Migrasi Masuk). Sebagian besar penduduk yang masuk ke Kota Makassar adalah penduduk yang berinisiatif untuk mendapatkan perekonomian yang lebih layak dan meningkatkan pendapatan dari daerah asalnya.

Kata Kunci: Migrasi, UMP, Investasi, Pengeluaran Pemerintah dan Kesempatan kerja. 


\section{Abstract: What is Affecting Migration Phenomenon into The City}

Population dynamics are due to the dynamics of birth, death and population movement to changes in population numbers, composition and growth. The growth of the labor force is not proportional to the provision of employment which means that the unemployment rate is getting bigger, the labor conditions that encourage increased mobilization among the population. Population movement from rural to urban is mostly influenced by economic factor that is hope to get better job opportunity in town. With a higher wage rate. In addition, an increased level of education will encourage residents to migrate for the purpose of obtaining employment opportunities appropriate to their level of education. The purpose of this study is to determine the relationship between the factors that affect migration interest to the city of Makassar. The study was conducted in Makassar with quantitative method and using secondary data. Equation model analysis is done by using panel data approach. The results showed that there are four factors that influence the population to migrate to Makassar city namely UMP, investment, government expenditure and employment opportunities. Where wage rates and employment are most strong influence on the incoming population to the City of Makassar (Migration Entrance). Most of the inhabitants who enter the city of Makassar are residents who take the initiative to get a more viable economy and increase revenue from the region of origin.

Keywords: Migration, Minimum Wage, Investment, Government Spending and Labor

\section{PENDAHULUAN / INTRODUCTION}

Perpindahan penduduk dari desa ke kota semakin tidak terhindarkan terjadinya di Kota Makassar. Dengan harapan untuk mendapatkan kesempatan kerja yang lebih baik di perkotaan, meskipun dengan skill dan latar pendidikan yang tidak memadai, penduduk pedesaan tetap melakukan migrasi ke perkotaan. Permasalahan yang cukup krusial pun muncul, terkait dengan situasi tersebut yakni pertumbuhan angkatan kerja yang tidak sebanding dengan penyediaan lapangan kerja yang ada di Kota Makassar. Dampaknya, hal ini justru berdampak buruk terhadap performa perekonomian Kota Makassar, yang akan terbebani dengan jumlah pengangguran dan angka kemiskinan yang semakin membengkak. Dengan demikian, hal ini menjadi begitu penting bagi pemerintah untuk diketahui, mengapa penduduk desa tersebut semakin massif berpindah ke Kota Makassar, walaupun dengan segala keterbatasannya. Untuk itu, hal ini penting untuk diketahui, agar permasalahan yang dihadapi bagi pemerintah Kota Makassar dapat terselesaikan.

Pola migrasi di negara-negara berkembang menunjukan suatu pengalihan yaitu pemasukan migrasi ke daerah-daerah tertentu saja, khususnya di kota-kota besar. Fenomena ini pada dasarnya menggambarkan bahwa di negara-negara berkembang, kekuatan ekonomi masih terpusat di wilayah-wilayah tertentu saja, arah pergerakan 
penduduk ini juga di tentukan oleh beberapa faktor lain selain faktor ekonomi. Faktor-faktor yang mempengaruhi keputusan penduduk, untuk melakukan migrasi sangat banyak dan kompleks, karena migrasi itu adalah proses yang menyangkut individual-individual dengan karateristik ekonomi, sosial, pendidikan dan demografi, serta dapat membuat orang untuk mendapatkan pekerjaan yang lebih baik.

Penduduk yang meninggalkan daerah asalnya karena dirasakan kurang memberikan sumber kehidupan yang layak, menuju tempat lain anggap dapat memberikan harapan. Faktor-faktor yang mempengaruhi orang untuk migrasi sangat berperan dan rumit. Karena migrasi merupakan proses yang secara selektif mempengaruhi setiap individu dengan ciriciri ekonomi, sosial, pendidikan dan demokrafi tertentu. Kondisi sosial ekonomi di daerah yang tidak memungkinkan untuk memenuhi kebutuhan hidup, mendorong mobilisasi penduduk dengan tujuan mempunyai nilai dengan kefaedahan yang lebih tinggi di daerah tujuan. Salah satu cara baik dilakukan untuk mengatasi kesenjangan kesempatan ekonomi adalah dengan migrasi dari desa kekota. Pertumbuhan penduduk besar diikuti persebaran tidak mereta antara daerah dengan perekonomian yang cenderung terkonsentrasi diperkotaan mendorong masyarakat untuk bermigrasi.

Pertumbuhan ekonomi daerah perkotaan menunjukkan perkembangan yang sangat pesat. Akan tetapi, perkembangan ekonomi di daerah pedesaan adalah cukup lambat, sehingga terjadi ketimpangan pertumbuhan ekonomi antara perkotaan dan pedesaan. Proses migrasi dari desa ke kota disebabkan oleh semakin kurang menariknya kehidupan dipedesaan, kawasan pedesaan yang kegiatan ekonomi utamanya adalah pertanian sudah kehilangan daya saing secara drastis. Motivasi untuk berpindah adalah karena motif ekonomi, motif tersebut berkembang karna adanya ketimpangan ekonomi antara berbagai daerah. Oleh karena itu pengarahan penduduk cenderung ke kota yang memeliki kekuatan yang relatif dapat diharapkan memenuhi pamrih ekonominya. Arus migrasi dari desa ke kota sering kali melibatkan dampak negatif di kota besar. Pemerintah terhadap kesempatan kerja, fasilitas infrastruktur dan pelayanan kota seperti komunikasi, sekolah, rumah sakit, air, penerangan dan listrik cenderung meningkat.

Dalam mengatasi permasalahan tersebut telah diadakan usaha untuk membatasi arus migrasi masuk ke kota dan menciptakan lapangan kerja didaerah asal. Namun hal ini sering kali tidak berhasil karena kurangnya pemahaman tentang alasan orang berpindah beberapa kali kekota lain dan ada yang berpindah hanya untuk sementara waktu. Faktor lain biasanya berupa faktor alam atau faktor lain di luar alasan pribadi seperti bencana alam, penggusuran 
Moh. Isa Ashari, Ahmad Kafrawi Mahmud, Apakah yang Memengaruhi Fenomena Migrasi Masuk ...

lahan untuk keperluan proyek pemerintah, swasta, wabah penyakit atau karena mengikuti program transmigrasi umum.

Derajat pembangunan dan pertumbuhan ekonomi daerah atau negara yang berada antara satu dengan lain yang lebih menguntungkan secara ekonomis. Pada umumnya, migrasi tenaga kerja berasal dari lokasi yang memiliki kelebihan tenaga kerja dan yang berpenghasilan rendah menuju lokasi yang kekurangan tenaga kerja menurut bandiono, dkk (1999) dalam waktu atau yang mampu memberikan upah lebih tinggi. Gaya dan kehidupan perkotaan yang penuh dengan persaingan, padahal tidak semua pendatang ke daerah perkotaan siap untuk menghadapinya atau bahkan banyak diantara mereka yang tidak membayangkan ada kehidupan yang demikian. Peristiwa ini tidaklah mengherankan terjadi, karena adanya perbedaan struktur sosial antara desa dan kota. Adanya perbedaan nilai budaya dan nilai kemasyarakatan yang juga dialami penduduk pendatang dapat mengakibatkan mereka yang datang ke kota merasa kecewa dan frustasi.

Perpindahan penduduk (migrasi) dapat menimbulkan lapisan sosial baru yang dapat menimbulkan beban pada perkotaan, karena kebanyakan dari kaum migran yang tidak berhasil hidup dengan layak di kota, akan menjadi gelandangan dan membentuk daerah hunian liar yang sangat rentan terhadap terjadinya perilaku menyimpang termasuk juga kejahatan dengan pertumbuhan penduduk yang relatif cepat dan tidak diimbanginya pertumbuhan sarana dan prasarana yang ada juga dapat mengakibatkan terjadinya berbagai kasus penyimpangan perilaku dan pelanggaran norma-norma yang ada. 


\section{TINJAUAN TEORITIK / LITERATURE REVIEW}

Menurut Munir (1981), Migrasi adalah perpindahan penduduk dengan tujuan menetap dari suatu tempat ke temapat lain melampaui batas politik atau negara atau batas administratif atau batas bagian dalam suatu negara. Migrasi sering diartikan sebagai perpindahan yang relatif permanen dari suatu daerah ke daerah lain. Ada 2 dimensi penting yang perlu ditinjau dalam penelaahan migrasi, yaitu dimensi waktu dan dimensi daerah. Untuk dimensi waktu, ukuran yang pasti tidak ada karena sulit untuk menentukan berapa lama seseorang pindah tempat tinggal untuk dapat dianggap sebagai seorang migran, tetapi biasanya digunakan definisi yang ditentukan dalam sensus penduduk.

Dimensi daerah secara garis besar membedakan perpindahan antar negara yaitu perpindahan penduduk dari suatu negara ke negara lain yang disebut migrasi internasional dan perpindahan penduduk yang terjadi dalam satu negara misalnya antar propinsi, kota atau kesatuan administratif lainnya yang dikenal dengan migrasi intern. Perpindahan lokal yaitu perpindahan dari satu alamat ke alamat lain atau dari satu kota ke kota lain tapi masih dalam batas bagian dalam suatu negara misalnya dalam satu provinsi.

Dalam arti luas, definisi tentang migrasi adalah tempat tinggal mobilitas penduduk secara geografis yang meliputi semua gerakan (movement) penduduk yang melintasi batas wilayah tertentu dalam periode tertentu pula menurut mantra (1989: 20). Definisi migran menurut Perserikatan Bangsa-Bangsa : "a migrant is a person who changes his place of residence from one political or a administrative area to another." pengertian ini dikaitkan dengan pindah tempat tinggal secara permanen sebab selain itu dikenal pula "mover'yaitu orang yang pindah dari satu alamat ke alamat lain dan dari saturumah ke rumah lain dalam batas satu daerah kesatuan politik atauadministratif, misalnya pindah dalam satu Propinsi. Beberapa bentukperpindahan tempat (mobilitas) :

1. Perubahan tempat yang bersifat rutin, misalnya orang yang pulang balik kerja (Recurrent Movement).

2. Perubahan tempat yang tidak bersifat sementara sepertiperpidahan tempat tinggal bagi para pekerja musiman.

3. Perubahan tempat tinggal dengan tujuan menetap dan tidak kembali ke tempat semula (Non Recurrent Movement).

Dalam sosiologi menurut sifatnya mobilitas dibedakan menjadi dua, yaitu : 
Moh. Isa Ashari, Ahmad Kafrawi Mahmud, Apakah yang Memengaruhi Fenomena Migrasi Masuk ...

a. Mobilitas vertikal yaitu perubahan status sosial dengan melihat kedudukan generasi, misalnya melihat status kedudukan ayah.

b. Mobilitas horisontal yaitu perpindahan penduduk secara teritorial, spasial atau geografis.

Pendekatan migrasi yang sebelumnya menjadi tuntunan dan dituliskan dalam hadits Rasulullaw S.A.W atau dikenal dengan istilah Hijrah yaitu :

$$
\text { ومَنْ كَانَتْ هِجْرَتُهُ إِلَى دُنْيَا يُصِيبُعَا أَوْ امْرَأَةٍ يَنْكِحُعَا فَهِجْرَتُهُ إِلَى مَا هَاجَرَ إِلَيْهِ }
$$

Artinya:

Barang siapa yang hijrahnya untuk kepentingan duniawi, atau kepentingan wanita yang dinikahi, maka manfaat hijrahnya pun sesuai dengan apa yang dituju. Umar bin Khatab. (HR. Al- Bukhari).

Hadits ini juga mengisyaratkan bahwa hijrah itu ada yang syar'i, ada pula yang tidak. Hijrah yang syar'i adalah perpindahan untuk kepentingan tegaknya Islam, demi meraih ridha Allah. Sedangkan hijrah yang tidak bernilai syar'i adalah yang bukan kepentingan jalan Allah, dan tidak bertujuan meraih ridha-Nya. Oleh karena itu, supaya segalanya bernilai ibadah, ikhlaskan tujuan untuk mencari ridha Allah dan melakukannya berdasar syari'ah Allah, serta mengikuti sunnah Rasul-Nya.

Ketika dilihat dari ada atau tidaknya niatan untuk menetap di daerah tujuan, mobilitas penduduk dapat pula dibagi menjadi dua, yaitu mobilitas penduduk permanen dan mobilitas penduduk non permanen. Jadi, migrasi adalah gerak penduduk yang melintasi batas wilayah menuju ke wilayah lain dengan ada niatan untuk menetap di daerah tujuan.

Sebaliknya mobilitas penduduk non permanen ialah gerak penduduk dari satu wilayah ke wilayah lain dengan tidak ada niatan untuk menetap di daerah tujuan. Apabila seseorang menuju ke daerah lain dan sejak semula sudah bermaksud tidak menetap di daerah tujuan, orang tersebut digolongkan sebagai pelaku mobilitas non permanen walaupun bertempat tinggal didaerah tujuan dalam jangka waktu cukup lama menurut Steele (Dina, 2008).

Gerak penduduk non permanen (sirkulasi : circulation) ini dapat pula dibagi menjadi dua yaitu ulang alik (nglaju/commuting) dan dapat menginap/mondok di daerah tujuan. Ulang alik adalah gerak penduduk 33 dari daerah asal menuju ke daerah tujuan dalam batas waktu tertentu kembali ke daerah asal pada hari itu juga. Pada umumnya penduduk yang 
melakukan mobilitas ingin kembali ke daerah secepatnya sehingga kalau dibandingkan frekuensi penduduk yang melakukan mobilitas ulang alik, menginap/mondok, dan migrasi frekuensi mobilitas penduduk yang ulang alik terbesar disusul oleh menginap/mondok, dan migrasi.

Secara operasional, macam-macam bentuk mobilitas penduduk tersebut diukur berdasarkan konsep ruang dan waktu. Misalnya, mobilitas ulang alik, konsep waktunya diukur dengan enam jam atau lebih meninggalkan daerah asal dan kembali pada hari yang sama, menginap/mondok diukur dari meninggalkan daerah asal lebih dari satu hari tetapi kurang dari enam bulan, sedangkan mobilitas permanen diukur darilamanya meninggalkan daerah asal enam bulan atau lebih kecuali orang yang sejak semula berniat menetap di daerah tujuan, seperti seorang istri yang mengikuti suaminya.

Sifat dan perilaku migran sirkuler di daerah tujuan yang bekerja tidak mengenal waktu karena mereka berusaha mempergunakan waktu untuk bekerja sebanyak mungkin agar mendapatkan upah sebanyak mungkin untuk dikirim ke daerah asal. Di daerah tujuan mereka tidak dikenai kewajiban untuk kerja bakti, ronda malam dan bergotong royong memperbaiki prasarana jalan atau saluran irigasi. Jadi, di daerah tujuan mereka mempunyai kesempatan berusaha keras untuk mendapatkan upah sebanyak-banyaknya.

Menurut Hugo (1981) migrasi dilakukan seseorang karena adanya tekanan lingkungan alam, ekonomi, sosial dan budaya. Menghadapi tekanan lingkungan ini ada tiga kemungkinan yang dilakukan masyarakat. Pertama, mereka yang bertahan di tempat, karena menganggap tempat yang sekarang adalah tempat terbaik dan dianggap paling banyak memberikan kemungkinan bagi terpenuhinya kebutuhan hidup tentu saja tidak dilupakan kemungkinan usaha perbaikan lingkungan hidupnya dan pembaharuan. Kedua, mereka pindah tempat atau migrasi. Ketiga, mereka melakukan peralihan antara keduanya, yaitu tetap tinggal tinggal di tempat lama tetapi mencari pekerjaan baru secara berkala dan terus menerus atau commutery.

Pendekatan migrasi pada suatu daerah dapat dipengaruhi dengan adanya teori "Kebutuhan \& Tekanan", Menurut Murray (1938), kebutuhan adalah suatu konstruk (fiksi atau konsep hipotesis) yang mewakili suatu daya dalam diri seorang individu pada bagian otak, kekuatan yang mengatur persepsi, apersepsi, pemahaman, konasi, dan kegiatan sedemikian rupa untuk mengubah situasi yang ada dan yang tidak memuaskan ke arah tertentu. Kebutuhan kadang-kadang langsung dibangkitkan oleh proses-proses internal tertentu pada diri seorang individu, tetapi lebih sering (bila dalam keadaan siap) oleh 
Moh. Isa Ashari, Ahmad Kafrawi Mahmud, Apakah yang Memengaruhi Fenomena Migrasi Masuk ...

terjadinya salah satu dari sejumlah kecil tekanan yang secara umum efektif (pengaruhpengaruh lingkungan) dalam diri seorang individu.

Seperti ketika seseorang mendapatkan tekanan di lingkungannya tersebut maka seseorang tersebut berinisiatif untuk meninggalkan kota atau daerah tersebut akibat adanya berbagai tekanan dan kebutuhan yang tidak sesuai.

Secara lebih rinci, berikut dapat memerhatikan kerangka pikir penelitian yang dilakukan, yaitu sebagai berikut :

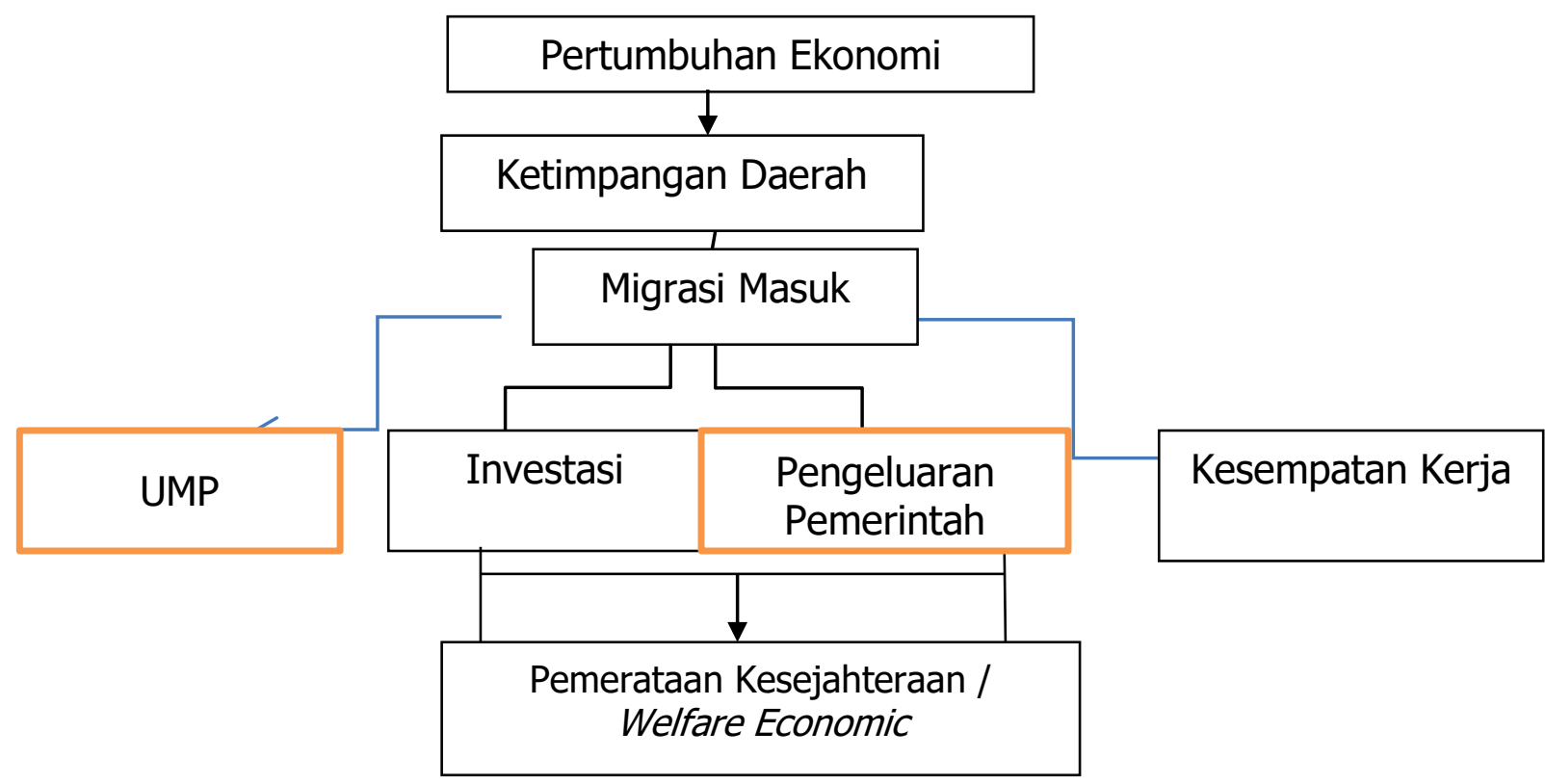

Teori migrasi awalnya diperkenalkan oleh Ravenstein (1985) dan kemudian digunakan sebagai dasar kajian bagi para peneliti lainnya. Menurut Lee (1976) Para peneliti tersebut mengatakan bahwa motif utama atau faktor primer yang menyebabkan seseorang melakukan migrasi adalah karena alasan ekonomi. Teori migrasi menurut Ravenstein (1985) mengungkapkan tentang perilaku mobilisasi penduduk (migrasi) yang disebut dengan hukum-hukum migrasi dan berkenaan sampai sekarang. Beberapa diantaranya adalah sebagai berikut :

1. Para migran cenderung memilih tempat tinggal terdekat dengan daerah tujuan.

2. Faktor yang paling dominan yang mempengaruhi seseorang untukbermigrasi adalah sulitnya memperoleh pendapatan di daerah asal dankemungkinan untuk memperoleh pendapatan yang lebih baik di daerah.

3. Berita-berita dari sanak saudara atau teman yang telah pindah ke daerah lain merupakan informasi yang sangat penting. 
4. Informasi yang negatif dari daerah tujuan mengurangi niat penduduk untuk bermigrasi.

5. Semakin tinggi pengaruh kekotaan terhadap seseorang, semakin besar tingkat mobilitas orang tersebut.

6. Semakin tinggi pendapatan seseorang, semakin tinggi frekuensi mobilitas orang tersebut.

7. Para migran cenderung memilih daerah dimana telah terdapat teman atau sanak saudara yang bertempat tinggal di daerah tujuan.

8. Pola migrasi bagi seseorang maupun sekelompok penduduk sulit untuk diperkirakan.

9. Penduduk yang masih muda dan belum menikah lebih banyak melakukan migrasi dibandingkan mereka yang berstatus menikah.

10. Penduduk yang mempunyai tingkat pendidikan tinggi biasanya lebih banyak mobilitasnya dibandingkan yang berpendidikan rendah.

Tjiptoherijanto (2000) menyatakan bahwa dalam arti yang luas migrasi adalah perubahan tempat tinggal secara permanen atau semi permanen. Dalam pengertian yang demikian, tidak ada pembatasan baik pada jarak perpindahan maupun sifatnya, serta tidak adanya perbedaan antara migrasi dalam negeri dan luar negeri. Migrasi menyimpan sejarahnya sendiri, yang sebenarnya tidak dapat dipisahkan dari sejarah perkembangan segala macam faham atau "isme" yang pernah berlaku, khususnya mengenai buruh yang diawali dengan perdagangan budak beberapa abad silam sampai kepada mobilitas tenaga kerja di masa kolonial. Sejarah kehidupan bangsa diwarnai dengan adanya migrasi, dan oleh karena itu pula terjadi proses pencampuran darah dan kehidupan kebudayaan.

Selain model migrasi tersebut, terdapat model yang dikembangkan menurut Speare (1975). Ia mengatakan bahwa migrasi tenaga kerja juga dipengaruhi oleh faktor struktural seperti karakteristik sosio - demografis, tingkat kepuasan terhadap tempat tinggal, kondisi geografis daerah asal, dan karakteristik komunitas. Pada umumnya ketidakpuasan pada latar belakang yang berdimensi struktural ini akan dapat mempengaruhi seseorang untuk bermigrasi. Sebagai contoh, daerah yang lahan pertaniannya tandus biasanya sebagian besar masyarakatnya akan mencari pekerjaan di tempat lain yang lebih subur atau banyak peluang ekonomi, khususnya pada sektor non pertanian, misalnya industri, perdagangan dan jasa. 
Moh. Isa Ashari, Ahmad Kafrawi Mahmud, Apakah yang Memengaruhi Fenomena Migrasi Masuk ...

Menurut Lee (1976) mengungkapkan bahwa volume migrasi di satu wilayah berkembang sesuai dengan keanekaragaman daerah-daerah di dalam wilayah tersebut. Bila melukiskan di daerah asal dan daerah tujuan ada faktor-faktor positif, negatif dan adapula faktor-faktor netral. Faktor positif adalah faktor yang memberi nilai yang menguntungkan kalau bertempat tinggal di daerah tersebut, misalnya di daerah tersebut terdapat sekolah, kesempatan kerja, dan iklim yang baik.

Sedangkan faktor negatif adalah faktor yang memberi nilai negatif pada daerah yang bersangkutan sehingga seseorang ingin pindah dari tempat tersebut. Perbedaan nilai kumulatif antara kedua tempat cenderung menimbulkan arus imigrasi penduduk. Selanjutnya menurut Lee (1976) menambahkan bahwa besar kecilnya arus migrasi juga dipengaruhi rintangan, misalnya ongkos pindah yang tinggi dan menurutnya terdapat empat faktor yang perlu diperhatikan dalam proses migrasi penduduk antara lain :

1. Faktor-faktor yang terdapat di daerah asal

2. Faktor-faktor yang terdapat di tempat tujuan

3. Rintangan antara daerah asal dan daerah tujuan

4. Faktor-faktor daerah asal dan daerah tujuan.

Faktor penyebab terjadinya migrasi, Menurut Hugo (1981) migrasi dilakukan seseorang karena adanya tekanan lingkungan alam, ekonomi, sosial dan budaya. Menghadapi tekanan lingkungan ini ada tiga kemungkinan yang dilakukan masyarakat. Pertama, mereka yang bertahan di tempat, karena menganggap tempat yang sekarang adalah tempat terbaik dan dianggap paling banyak memberikan kemungkinan bagi terpenuhinya kebutuhan hidup tentu saja tidak dilupakan kemungkinan usaha perbaikan lingkungan hidupnya dan pembaharuan. Kedua, mereka pindah tempat atau migrasi. Ketiga, mereka melakukan peralihan antara keduanya, yaitu tetap tinggal tinggal di tempat lama tetapi mencari pekerjaan baru secara berkala dan terus menerus atau commutery.

Pada dasarnya faktor-faktor orang yang melakukan migrasi dibagi menjadi dua, yaitu faktor pendorong dan faktor penarik.

a. faktor pendorong:

1. Berkurangnya lapangan pekerjaaan di tempat asal

2. Bencan alam seperti banjir, gempa bumi, gunung meletus dll

3. Adanya wabah penyakit berbahaya

4. Makin berkurangnya sumber-sumber alam ditempat asal

5. Adanya tekanan atau diskriminasi politik, agama atau suku di daerah asal

6. Alasan perkawinan atau pekerjaan yang mengharuskan pindah dari daerah asal. 


\section{b. Faktor penarik}

1. Adanya rasa kecocokan di tempat yang baru atau kesempatan untuk memasuki lapangan pekerjaan yang cocok

2. Kesempatan untuk mendapatkan pendapatan yang lebih baik

3. Kesempatan untuk mendapatkan pendidikan yang lebih tinggi

4. Keadaan lingkungan dan keadaan hidup yang menyenangkan

Selanjutnya dilakukan penjelasan terkait masing-masing variabel yang digunakan dalam melakukan estimasi berdasarkan permasalahan dan model ekonomi yang diajukan dalam persamaan, sebagai berikut :

Upah minimum adalah suatu standar minimum yang digunakan oleh para pengusaha atau pelaku industri untuk memberikan upah kepada pekerja di dalam lingkungn usaha atu kerjanya. Karena pemenuhan kebutuhan yang layak di setiap provinsi berbeda-beda, maka disebut Upah Minimum Provinsi. Menurut Permen No. 1 tahun 1999 Pasal 1 ayat 1, upah minimum adalah upah bulanan terendah yang terdiri dari upah pokok sedikit-sedikitnya $75 \%$ dari jumlah upah pokok dan tunjangan tetap. Definisi tunjangan tetap disini adalah tunjangan yang pembayarannya dilakukan secara teratur dan tidak dikaitkan dengan kehadiran atau pencapaian prestasi kerja contohnya: tunjangan jabatan, tunjangan komunikasi, tunjangan keluarga, tunjangan keahlian/profesi. Beda halnya dengan tunjangan makan dan transportasi, tunjangan itu bersifat tidak tetap karena perhitungannya berdasarkan kehadiran atau performa kerja.

Investasi dapat diartikan sebagai pengeluaran atau pembelanjaan penanampenanam modal atau perusahaan untuk membeli barang-barang modal dan perlengkapanperlengkapan produksi untuk menambah kemampuan memproduksi barang-barang dan jasa-jasa yang tersedia dalam perekonomian menurut sukirno (1994:107).

Investasi merupakan kegiatan dala menanamkan modal dana dalam suatu bidang tertentu. Investasi dapat dilakukan melalui berbagai cara, salah satunya yaitu investasi dalam bentuk saham. Investor dapat menanamkan kelebihan dananya dalam bentuk saham di pasar bursa. Tujuan utama investor dalam menanamkan dananya ke bursa efek yaitu untuk mencari pendapatam atau tingkat pengambilan investasi (return) baik berupa pendapatan dividen maupun pendapatan dari selisih harga jual saham terhadap harga belinya (caital gain). 
Moh. Isa Ashari, Ahmad Kafrawi Mahmud, Apakah yang Memengaruhi Fenomena Migrasi Masuk ...

Pengeluaran Pemerintah (goverment expenditure) adalah bagian dari kebijakan fiskal menurut sukirno (2000), yaitu suatu tindakan pemerintah untuk mengatur jalannya perekonomian dengan cara menentukan besarnya penerimaan dan pengeluaran pemerintah setiap tahunnya, yang tercermin dalam dokumen Anggaran Pendapatan Belanja Negara (APBN) untuk nasional dan Anggaran Pendapatan Belanja Daerah (APBD) untuk daerah atau regional. Tujuan dari kebijakan fiskal ini adalah dalam rangka menstabilkan harga, tingkat output, maupun kesempatan kerja dan memacu atau mendorong pertumbuhan ekonomi.

Menurut Keynes dalam (Sukirno 2000) bahwa peranan atau campur tangan pemerintah masih sangat diperlukan yaitu apabila perekonomian sepenuhnya diatur olah kegiatan di pasar bebas, bukan saja perekonomian tidak selalu mencapai tingkat kesemptan kerja penuh tetapi juga kestabilan kegiatan ekonomi tidak dapat diwujudkan. Akan tetapi fluktuasi kegiatan ekonomi yang lebar dari satu periode ke periode lainnya dan ini akan menimbulkan implikasi yang serius kepada kesempatan kerja dan pengangguran dan tingkat harga.

Kesempatan kerja merupakan hubungan antara angkatan kerja dengan kemampuan penyerapan tenaga kerja. Pertambahan angkatan kerja harus diimbangi dengan investasi yang dapat menciptakan kesempatan kerja. Dengan demikian, dapat menyerap pertambahan angkatan kerja.

Dalam ilmu ekonomi, kesempatan kerja berarti peluang atau keadaan yang menunjukkan tersedianya lapangan pekerjaan sehingga semua orang yang bersedia dan sanggup bekerja dalam proses produksi dapat memperoleh pekerjaan sesuai dengan keahlian, keterampilan dan bakatnya masing-masing. Kesempatan Kerja (demand for labour) adalah suatu keadaan yang menggambarkan/ketersediaan pekerjaan (lapangan kerja untuk diisi oleh para pencari kerja). Dengan demikian kesempatan kerja dapat diartikan sebagai permintaan atas tenaga kerja.

Kesempatan kerja dalam menyerap tenaga kerja merupakan suatu masalah utama dalam pembangunan Indonesia, baik di masa lampau maupun di masa yang akan dating. Ledakan penduduk dari tahun ke tahun terus meningkat, sementara lapangan kerja untuk menampung mereka tidak memadai.

Menurut Sumarsono (2003 : 41) memberikan definisi bahwa kesempatan kerja adalah lapangan pekerjaan yang sudah di duduki (employment) dan masih lowongan (vacancy). Lebih jauh di jelaskan bahwa dalam teori kesempatan kerja di kenal istilah elastisitas pemerintah akan tenaga kerja yang di artikan sebagai persentase perubahan permintaan 
akan tenaga kerja sehubungan dengan perubahan permintaan akan tenaga kerja yang di sebabkan dengan perubahan satu persen pada tingkat upah.

\section{METODE PENELITIAN / METHODS}

Metode analisis yang digunakan untuk mengestimasi hasil pada penelitian ini yaitu dengan menggunakan analisis data panel. Dimana pendekatan data panel adalah analisis regresi dengan struktur data yang umumnya menjadi pendugaan parameter dalam analisis regresi yang menggabungkan antara data time series dan cross section. Proses regresi yang dilakukan menggunakan pendugaan dengan metode kuadrat terkecil atau disebut Ordinary Least Square (OLS).

Regresi Data Panel adalah gabungan antara data cross section dan data time series, dimana unit cross section yang sama diukur pada waktu yang berbeda. Maka dengan kata lain, data panel merupakan data dari beberapa individu sama yang diamati dalam kurun waktu tertentu. Jika kita memiliki $\mathrm{T}$ periode waktu $(\mathrm{t}=1,2, \ldots, \mathrm{T})$ dan $\mathrm{N}$ jumlah individu ( $\mathrm{i}=$ $1,2, \ldots, N)$, maka dengan data panel kita akan memiliki total unit observasi sebanyak NT. Jika jumlah unit waktu sama untuk setiap individu, maka data disebut balanced panel. Jika sebaliknya, yakni jumlah unit waktu berbeda untuk setiap individu, maka disebut unbalanced panel.

Two Way Model adalah model yang mempertimbangkan efek dari waktu atau memasukkan variabel waktu. Berikut Persamaannya:

\section{Migrasi it $=a+\beta 1$ MPit $+\beta 2$ Investit $+\beta 3$ GovEXP it $+\beta 4$ WorkOpp it + cit}

Keterangan :

Migrasi : Variabel Migrasi Masuk

UMP : Variabel Upah Minimum Provinsi

Invest : Variabel Tingkat Investasasi

GovExp : Variabel Pengeluaran Pemerintah

WorkOpp : Variabel Kesempatan Kerja

Metode Regresi Data Panel akan memberikan hasil pendugaan yang bersifat Best Linear Unbiased Estimation (BLUE) jika semua asumsi Gauss Markov terpenuhi diantaranya adalah non-autcorrelation. 
Moh. Isa Ashari, Ahmad Kafrawi Mahmud, Apakah yang Memengaruhi Fenomena Migrasi Masuk ...

Non-autocorrelation inilah yang sulit terpenuhi pada saat kita melakukan analisis pada data panel. Sehingga pendugaan parameter tidak lagi bersifat BLUE. Jika data panel dianalisis dengan pendekatan model-model time seriesseperti fungsi transfer, maka ada informasi keragaman dari unit cross section yang diabaikan dalam pemodelan. Salah satu keuntungan dari analisis regresi data panel adalah mempertimbangkan keragamaan yang terjadi dalam unit cross section.

Penelitian yang dilakukan menggunakan data dari tahun 2013 sampai tahun 2017 dengan data berdasarakan variabel yang digunakan dalam penelitian yaitu variabel tingkat migrasi masuk, variabel tingkat investasi (PMA \& PMDN) di Kota Makassar, variabel belanja pemerintah sektor pembangunan di Kota Makassar dan variabel kesempatan kerja di Kota Makassar.

\section{HASIL DAN PEMBAHASAN / DISCUSSION}

Jenis penelitian yang digunakan merupakan penelitian kuantitatif dengan menggunakan data sekunder dengan pendekatan panel data. Adapun variabel yang digunakan untuk dapat menjelaskan permasalahan penelitian yang telah diajukan yaitu Variabel migrasi masuk ke kota Makassar, tingkat upah kota Makassar, nilai investasi, pengeluaran pemerintah dan kesempatan kerja di kota Makassar.

Penelitian ini dilakukan di Kota Makassar Propinsi Sulawesi Selatan. Pemilihan dan penentuan kota Makasar sebagai daerah penelitian dikarenakan untuk memudahkan pengumpulan data, selain itu karena kota Makassar termasuk salah satu kota yang penduduk migrasinya meningkat setiap tahun dan terbesar khususnya untuk kota / ibukota yang berada di Kawasan Timur Indonesia.

Model penelitian yang digunakan bertujuan untuk melakukan estimasi dan untuk melihat pengaruh serta keterkaitan antara variabel dependen yaitu migrasi masuk, dengan variabel-variael independen yaitu variabel upah, investasi, pengeluaran pemerintah \& kesempatan kerja. Model penelitian dibuat dalam model persamaan ekonometrika dengan menggunakan regresi data panel dengan menggunakan pendekatan Random Effect Model . Berikut model yang digunakan dalam penelitian :

Vim it = BO+ B1 LnUMPit + B2 LnInvest it + B3 Govexp it + B4 LnWorkopp it + cit Keterangan :

IM : Migrasi Masuk 
Invest : Investasi (PMA \& PMDN)

UMP : Upah Minimum Provinsi

Govexp : Pengeluaran Pemerintah

Workopp : Kesempatan Kerja

Hasil Estimasi

\begin{tabular}{cccc}
\hline Variabel Dependen : IM $_{\mathrm{i}, \mathrm{t}}$ & \multicolumn{2}{c}{ Total Observasi } & $: 75$ \\
\hline Variabel Independen & Koefisien & t-statistik & Probabilitas \\
\hline C & -4460.798 & -2.102619 & 0.0393 \\
UMP? & 0.006436 & 4.288023 & 0.0001 \\
INVEST? & $-8.36 \mathrm{E}-11$ & -0.085497 & 0.9321 \\
GOVEXP? & $-1.34 \mathrm{E}-10$ & -3.903263 & 0.0002 \\
WORKOPP? & 0.024832 & 4.985177 & 0.0000 \\
R-Squared & & 0.758212 & \\
F-Statistik & & 10.42411 & \\
DW-Stat & & 2.429575 & \\
\hline
\end{tabular}

Sumber: Hasil Pengolahan Data dengan Eviews9

Berdasarkan hasil regresi tersebut, dapat diketahui bahwa variabel upah (UMP) dan variabel kesempatan kerja (Workopp) berpengaruh signifikan dan positif dengan besaran nilai koefisiennya yaitu 0.006436 dan 0.024832 . Kemudian untuk variabel pengeluaran pemerintah (GovExp) berpengaruh signifikan namun bernilai negatif dengan nilai koefisien sebesar (-1.34E-10), selanjutnya untuk variabel investasi tidak signifikan dan berpengaruh negatif terhadap variabel dependen yaitu sebesar nilai koefisien $(-8.36 \mathrm{E}-11)$. Selain itu nilai C berpengaruh signifikan dengan nilai koefisien sebesar -4460.798 yang berarti bahwa ketika variabel dependen tidak dipengaruhi oleh variabel-variabel independen, maka nilainya sebesar nilai koefisien $\mathrm{C}$ tersebut.

Berdasarkan hasil pengolahan data, dapat diketahui Nilai $\mathrm{R}^{2}$ adalah sebesar 0.758212. Hal ini menunjukkan bahwa variabel-variabel independen pada model ini mampu menjelaskan atau dapat mempengaruhi variabel dependennya sebesar $75.82 \%$, sedangkan $24.18 \%$ dijelaskan oleh faktor-faktor lain diluar model.

Berdasarkan hasil regresi, UMP (X1) mempunyai nilai koefisien sebesar 0.006436 dengan nilai tstatistik sebesar 4.288023 dengan tingkat signifikan dimana tingkat profbabilitas adalah sebesar 0.0001 dimana nilainya < 0,05 sehingga dapat dikatakan signifikan pada $a=0.01$. hal ini menunjukkan bahwa upah terhadap jumlah penduduk 
Moh. Isa Ashari, Ahmad Kafrawi Mahmud, Apakah yang Memengaruhi Fenomena Migrasi Masuk ...

migran masuk (Risen) di kota Makassar adalah positif dan signifikan. Sehingga dapat dikatakan bahwa jika upah meningat $1 \%$ maka akan menyebabkan peningkatan jumlah penduduk migran masuk sebesar $0.006436 \%$. oleh karena variable UMP (X1) terbukti berpengaruh positif dan signifikan terhadap jumlah penduduk migran masuk $(Y)$.

Berdasarkan hasil regresi data panel diatas, investasi (X2) menunjukkan bahwa investasi secara statistik berpengaruh negatif dan tidak signifikan terhadap jumlah penduduk migran masuk (Risen). Dimana nilai koefisiennya sebesar -8.36E-11 dan statistik tstatistik sebesar -0.085497 dengan tingkat signifikan dimana tingkat profitabilitas adalah sebesar 0.9321 dimana nilainya > 0,05 sehingga dapat dikatakan tidak signifikan. Oleh karena itu, variable Investasi terbukti berpengaruh negatif dan tidak signifikan terhadap jumlah penduduk migran masuk.

Hasil dari regresi pengeluaran pemerintah (X3) mempunyai nilai koefisien sebesar 1.34E-10 dan tstatistik sebesar -3.903263 dengan tingkat signifikan dan tingkat profitabilitas sebesar 0.0002 dimana nilai $<0.05$ sehingga dapat dikatakan signifikan pada $a=0,01$. Hasil tersebut menunjukkan bahwa pengeluaran pemerintah secara statistik signifikan pada taraf 5\%, namun pengaruhnya tersebut bernilai negatif yaitu sebesar 1.34E-10. Sehingga dapat dikatakan bahwa jika pengeluaran pemerintah meningkat $1 \%$ maka jumlah penduduk migran masuk (Risen) akan berkurang sebesar $-1.34 \mathrm{E}-10 \%$. Oleh karena itu variabel pengeluaran pemerintah terbukti berpengaruh negatif dan signifikan terhadap jumlah penduduk miigran masuk (risen) $(\mathrm{Y})$.

Hasil dari regresi, investasi (X4), mempunyai nilai koefisien 0.024832 dan statistik tstatistik sebesar 4.9851774 dengan tingkat signifikan dimana tingkat profitabilitas adalah sebesar 0.0000 dimana nilainya $<0,05$ sehingga dapat dikatakan signifikan pada $a=0,01$. Hal ini menunjukkan bahwa kesempatan kerja berpengaruh positif dan signikfikan terhadap jumlah penduduk migran masuk (Risen) di Kota Makassar. Ini berarti bahwa jika kesempatan kerja meningkat $1 \%$ maka jumlah penduduk migran yang masuk ke Kota Makassar akan naik sebesar $0.024832 \%$. karena variabel kesempatan kerja terbukti berpengaruh positif dan signifikan terhadap jumlah penduduk migran masuk $(Y)$.

\section{Variabel Migrasi Masuk terhadap Tingkat Upah (UMP)}

UMP (X1) mempunyai nilai koefisien sebesar 0.006436 dengan nilai t-statistik sebesar 4.288023 dengan tingkat signifikan dan profbabilitas adalah sebesar 0.0001 dimana nilainya $<0,05$ sehingga dapat dikatakan signifikan pada $a=0.01$. hal ini menunjukkan bahwa upah terhadap jumlah penduduk migran masuk (Risen) di kota Makassar adalah positif dan 


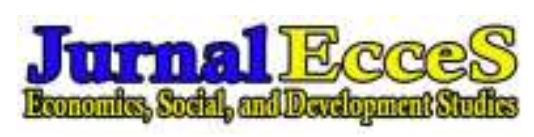

Volume 5 Nomor1 Ed.Juni 2018 : page 61-79 p-ISSN: 2407-6635 e-ISSN : 2580-5570

signifikan. Sehingga dapat dikatakan bahwa jika upah meningat $1 \%$ maka akan menyebabkan peningkatan jumlah penduduk migran masuk sebesar $0.006436 \%$.

\section{Variabel Migrasi Masuk terhadap Tingkat Investasi}

Investasi (X2) menunjukkan bahwa investasi secara statistik berpengaruh negatif dan tidak signifikan terhadap jumlah penduduk migran masuk (Risen). Dimana nilai koefisiennya sebesar -8.36E-11 dan statistik tstatistik sebesar -0.085497 dengan tingkat signifikan dimana tingkat profitabilitas adalah sebesar 0.9321 dimana nilainya $>0,05$ sehingga dapat dikatakan tidak signifikan.

\section{Variabel Migrasi Masuk terhadap Pengeluaran Pemerintah (GOVEXP)}

Pengeluaran pemerintah (X3) mempunyai nilai koefisien sebesar $-1.34 \mathrm{E}-10$ dan tstatistik sebesar -3.903263 dengan tingkat signifikan profitabilitas sebesar 0.0002 dimana nilai $<0.05$ sehingga dapat dikatakan signifikan pada $a=0,01$. Hasil tersebut menunjukkan bahwa pengeluaran pemerintah secara statistik signifikan pada taraf $5 \%$, namun pengaruhnya tersebut bernilai negatif yaitu sebesar $-1.34 \mathrm{E}-10$. Sehingga dapat dikatakan bahwa jika pengeluaran pemerintah meningkat $1 \%$ maka jumlah penduduk migran masuk (Risen) akan berkurang sebesar -1.34E-10\%.

\section{Variabel Migrasi Masuk terhadap Kesempatan Kerja (WORKOPP)}

Investasi (X4), mempunyai nilai koefisien 0.024832 dan t-statistik sebesar 4.9851774 dengan tingkat signifikan sebesar 0.0000 dimana nilainya $<0,05$ sehingga dapat dikatakan signifikan pada $a=0,01$. Hal ini menunjukkan bahwa kesempatan kerja berpengaruh positif dan signikfikan terhadap jumlah penduduk migran masuk (Risen) di Kota Makassar. Ini berarti bahwa jika kesempatan kerja meningkat $1 \%$ maka jumlah penduduk migran yang masuk ke Kota Makassar akan naik sebesar 0.024832\%.

\section{KESIMPULAN / CONCLUSION}

Berdasarkan dari hasil penelitian yang telah dilakukan dengan pendekatan metode kuantitatif dan menggunakan data sekunder, bahwa yang memengaruhi penduduk atau masyarakat untuk melakukan migrasi masuk ke Kota Makassar adalah karena mendapat pengaruh dari beberapa variabel yaitu tingkat upah, investasi Kota Makassar, pengeluaran pemerintah, dan kesempatan kerja di Kota Makassar.

Pada hasil penelitian dimana tingkat upah dan kesempatan kerja paling kuat memberikan pengaruh terhadap penduduk yang masuk ke Kota Makassar (Migrasi Masuk). Olehnya itu, maka dapat diketahui bahwa sebagian besar penduduk yang masuk ke Kota 
Moh. Isa Ashari, Ahmad Kafrawi Mahmud, Apakah yang Memengaruhi Fenomena Migrasi Masuk ...

Makassar adalah penduduk yang berinisiatif untuk mendapatkan pekerjaan dan meningkatkan perekonomian yang lebih layak dan meningkatkan pendapatan dari daerah asalnya.

\section{DAFTAR PUSTAKA / REFERENCES}

Bandiono, S dan Alihar, F. 1999. Tinjauan Penelitian Migrasi Internasional di Indonesia, Bandung: Penerbit Alumni.

BPS Kota Makassar. Jumlah penduduk Kota Makassar, PDRB, UMP, Migrasi Masuk, Pengeluaran Penerintah, Kesempatan Kerja di Kota Makassar 2003-2017

Didit Purnomo, SE. 2004. Studi Tentang Pola Migrasi Sirkuler Asal Wonogiri ke Jakarta. MIESP Fakultas Ekonomi Universitas Diponegoro, Semarang.

Dinas Penanaman Modal Makassar (BKPM). Perkembangan nvestasi Kota Makassar

Guritno. Algifari, Mangkoesoebroto.1998. Teori Ekonomi Makro.Yogyakarta:STIE YKPN.

Hugo. Graeme J, (1981). Population and Mobility in West Java, Disertasi . Yogya-karta : Gadjah Mada University Press

Kuncoro, Mudrajad. 2012. Perencanaan Membangun Ekonomi Lokal, Kota dan Kawasan, Jakarta: Penerbit Salemba Empat, Jakarta Selatan.

Lee, Everett. S. 1976. Teori Migrasi. Pusat Penelitian Kependudukan UGM. Yogyakarta.

Mantra. I. Abustam. (1989: 20). Gerak Penduduk Pembangunan dan Perubahan Sosial. Jakarta : Universitas Indonesia.

Mantra, Ida Bagoes, Tukiran, Kasto, dan R. Riyanto (waridin 2002). Teori Dan Metodologi Studi Kependudukan. Yogyakarta: Pusat Antar Universitas, Universitas Gadjah Mada.

Munir, R. (1981). Dasar - Dasar Demografi Migrasi . Jakarta: Lembaga Demografi UI.

Murray, H. 1983. Explorations In Personality. New York : Oxford University Press

Nuraini Atik. 2006. Analisis Faktor - faktor Yang Mempengaruhi Minat Migrasi Sirkuler Menginap/Mondok (Studi Kasus Kabupaten Boyolali). Skripsi S1(tidak dipublikasikan) FE UNDIP : Semarang.

Puspitasari. Ayu Wulan. 2010. Analisis Faktor - faktor Yang Mempengaruhi Minat Migrasi Sirkuler ke Semarang.

Ravenstein, 1985. Teori Migrasi. Pusat Penelitian Kependudukan UGM. Yogyakarta.

Tjiptoherijanto, Prijono. (2000). Mobilitas Penduduk dan Pembangunan Ekonomi. Simposium Dua Hari Kantor Mentrans dan Kependudukan/BAKMP di Jakarta Naskah No.20 , 110. 
Rahanatha, Bayu, 2008, Skema Pembentukan Positioning Terhadap Pendengar Dari Sebuah Stasiun Radio, Jakarta : Visuo

Soliha, E., Taswan. (2002). Pengaruh Kebijakan Hutang Terhadap Nilai Perusahaan Serta Beberapa Faktor Yang Mempengaruhinya. Jurnal Ekonomi dan Bisnis, STIE Stikubank Semarang, 1-18.

Sukirno, Sadono. 2000. Makroekonomi Modern. Jakarta: PT Raja Drafindo Persada.

Sumarsono, Sonny. 2003. Ekonomi Manajemen Sumber Daya Manusia dan Ketenagakerjaan. Yogyakarta : Graha Ilmu.

Sunariyah, 2003. Pengantar Pengetahuan Pasar Modal, edisi ke tiga, UPP-AMP YKPN, Yogyakarta

Speare Jr, A. 1975 Interpreting the Migration Data from the 1971 Cencus. Majalah Demografi Indonesia, 2 (3), 1975. hal 66 - 68

Widarjono Agus. 2009. Ekonometrika Pengantar dan Aplikasinya.Edisi Ketiga. EKONISIA. Yogyakarta 
